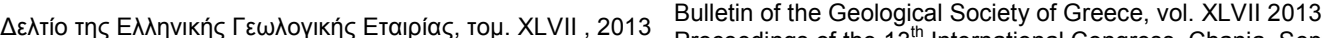
Proceedings of the $13^{\text {th }}$ International Congress, Chania, Sept.

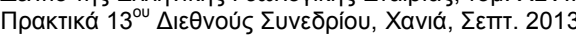
2013

\title{
PALAEOBOTANICAL STUDY OF POLICHNITOS REGION, SOUTHERN PART OF LESBOS ISLAND, GREECE (PRELIMINARY RESULTS ON ANGIOSPERM WOOD)
}

\author{
Mantzouka D. ${ }^{1}$, Sakala J. $^{2}$, Kvaček Z. ${ }^{2}$ and Karakitsios V. ${ }^{1}$ \\ ${ }^{I}$ National and Kapodistrian University of Athens, Faculty of Geology and Geoenvironment, \\ Department of Hist.Geology - Paleontology,dmantzouka@geol.uoa.gr,vkarak@geol.uoa.gr \\ ${ }^{2}$ Charles University of Prague, Czech Republic, Institute of Geology and Palaeontology, Albertov \\ 6, 12843,Prague 2,rade@natur.cuni.cz,kvacek@natur.cuni.cz
}

\begin{abstract}
The present contribution brings new scientific data for the palaeoflora of Lesbos based on new collections of plant fossils which were discovered in 2011 at six new localities from the southern part of Lesbos Island. This study resumes the published data both on the palaeovegetation of the Petrified Forest and the palaeogeography of Lesbos Island during the Neogene.

The new palaeobotanical study with more than seventy new samples of fossilized wood from the broader area of Polichnitos region gives new information about the palaeobotanical and palaeontological content of this area.

It is reported for the first time here the existence of a diversified fossil wood assemblage from the southern part of the Island as long as the identification of three types of lauraceous wood according to their idioblasts characteristics.
\end{abstract}

Key words: plant fossil anatomy, Lauraceae, idioblasts, Petrified Forest of Lesbos.

\section{Пєрí $\eta \psi \eta$}

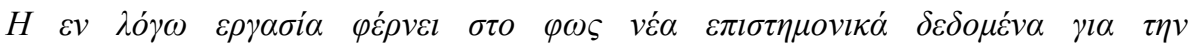

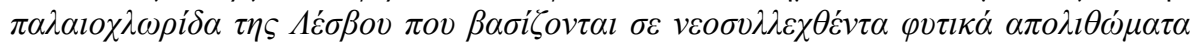

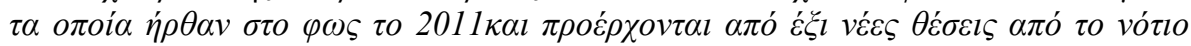

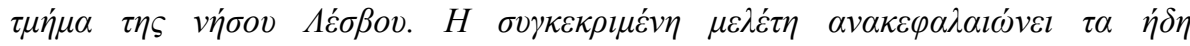

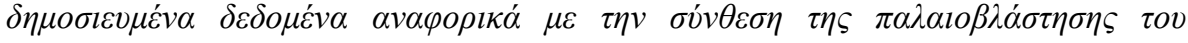

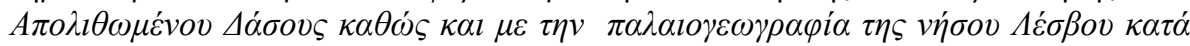

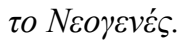

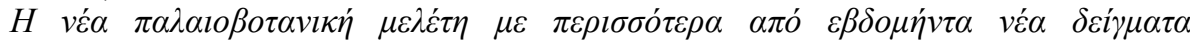

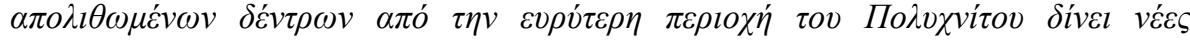

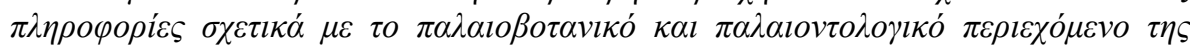

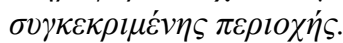

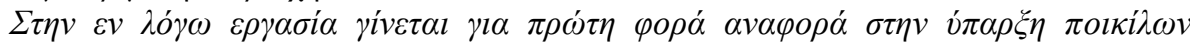

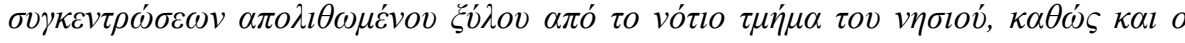

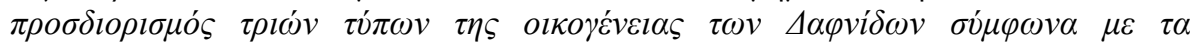

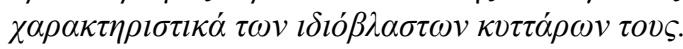

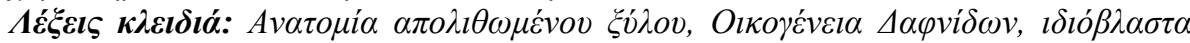

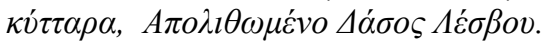

XLVII. No $1-204$ 


\section{Introduction}

The importance of the plant fossils of Lesbos Island has been underlined having also the privilege to be the first place of the world where the palaeobotanical research took place by Theophrastus from Eressos, Lesbos Island (372-287 B.C.) at the 3rd century B.C. Theophrastus wrote down all

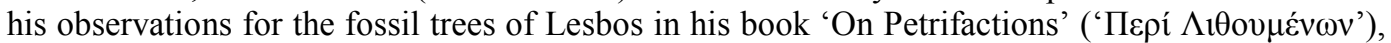
which, unfortunately is not saved, although there are some references about the fossil trees inside

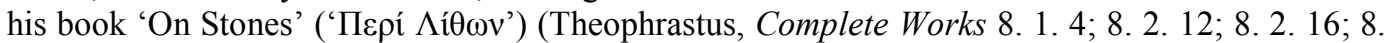
2. $17 ; 8$. 6. 38). The main occurrences of the plant fossils have been found at the western peninsula of the Island (Petrified Forest park; Nissiopi park; Sigri park; Plaka park; Skamiouda park) which has been declared as a Protected Natural Monument since 1985 with a special Presidential Decree (No 443/1985, in Velitzelos et al., 1999). Up to now the great majority of the studied woods were attributed to "gymnosperms" (especially conifers), while the described leaves belong rather to angiosperms (Velitzelos \& Zouros, 2008).

This study focuses on the new findings - of both conifers and angiosperms - from new plant fossiliferous localities from Polichnitos region (which is rather distant from the protected area of the Petrified Forest-Western Peninsula).

\section{Geological Setting}

Lesbos Island is located at the NE part of Aegean and it belongs to the Pelagonian geotectonic zone of Greece which represents a fragment of the Cimmerian Continent (Mountrakis, 1983; 1986).

According to previously published data (Hecht, 1972b; 1974, Katsikatsos et al. 1982; 1986, Fytikas et al., 1984, Mountrakis et al., 1983; 2001, Thomaidou, 2009) the geology of Lesbos is documented in Figure 1 and it consists of an autochnthonous and two allochthonous units.

Polichnitos - Vatera area is located at the southern part of the Lesbos Island (Figure 1). In this area there are six different localities from where samples of fossil wood were obtained. The stratigraphic sequence is presented in Figure 2.

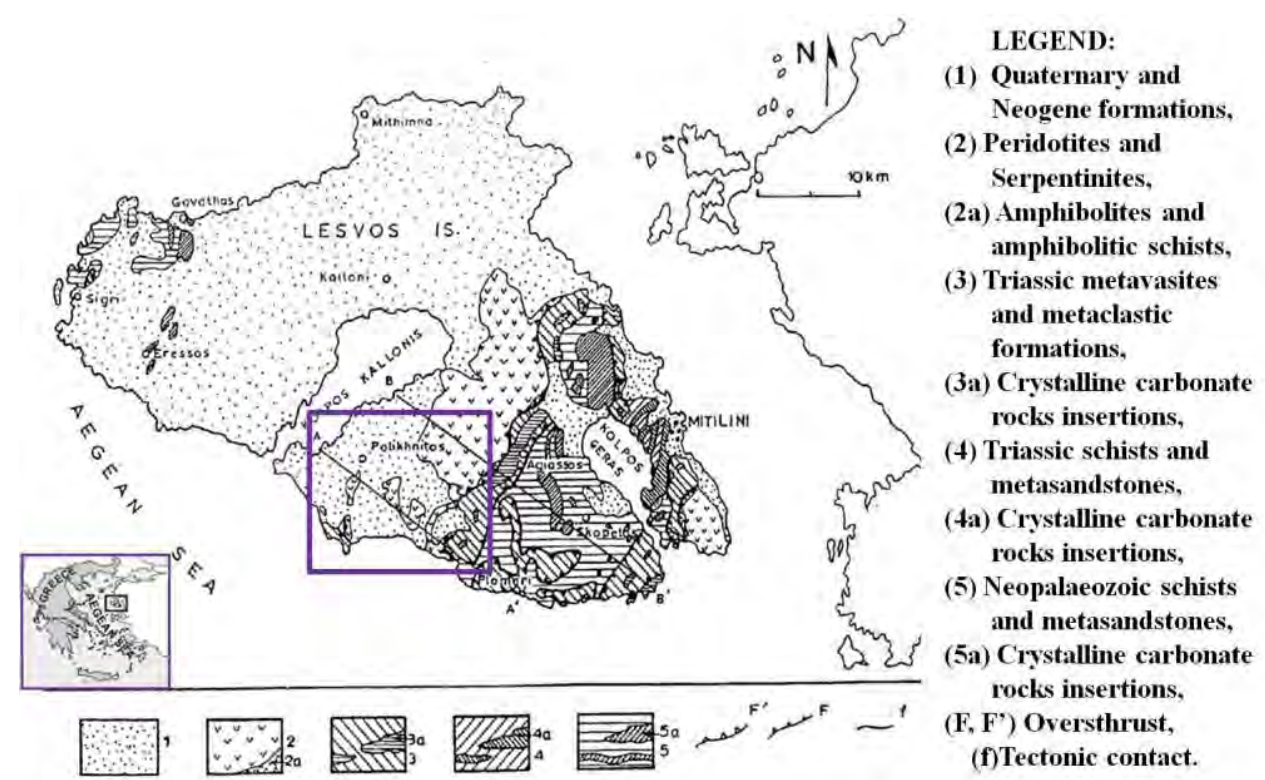

Figure 1 - Geological map by Katsikatsos et al. (1986), modified. Polichnitos-Vatera study area is included in the rectangular.

XLVII. No $1-205$ 
The stratigraphic sequence of our section fits almost perfectly with the one presented by Katsikatsos et al. (1982) for Polichnitos area, with the difference of a tephra horizon (formation 'e.i' in Fig.2) - which can be attributed to the 'volcanic rocks $(+)$ formation' - under Polichnitos ignimbrite (formation 'c' in Fig.2) as it is shown in Figure 2.

Our outcrops (from the bottom to the top layer) consist of:

- Miocene Terra rossa with a thickness of approximately $12 \mathrm{~m}$ (formation ' $b$ ' in Fig.2). This is the layer which has the same stratigraphic position with the thick deposits of conglomerates and pyroclastic materials of the area of Sigri - Antisa, which are also lying under the ignimbrites and have at their lower part (and mainly at their basis) marly layers which host small lignitic deposits (Katsikatsos et al., 1986). According to Lamera (2004) it might represent a 'lahar' formation. The basement / underlying layer is not seen at the outcrop but the general view of the area shows that the basement consists of ultrabasic rocks.

- Over the Terra rossa there is a tephra horizon of 1,5 m thickness (formation 'e. i' in Fig.2, left column) and over this there are volcanics of beige color - consisting of 2 horizons, one of $0,4 \mathrm{~m}$ ('e. ii' formation in Fig.2, left column) and one of $2 \mathrm{~m}$ thickness ('e. iii' formation in Fig.2, left column) - with a total thickness of $2.4 \mathrm{~m}$ which are underlying the

- Ignimbrite of Polichnitos with a thickness of $4 \mathrm{~m}$ (formation 'c' in Fig.2). According to Pe-Piper \& Piper, 1993 the only radiometric date of Polichnitos ignimbrite in $17.2 \pm 0.5 \mathrm{Ma}$ 'was made by Borsi et al. (1972) corrected to the Steiger \& Jäger, (1977) decay constant'. Polichnitos ignimbrite formation belongs to the magnetic epoch 17 with an age of 18.4 - 17.2 Ma (Pe-Piper, 1980; PePiper \& Piper, 1993 while, according to the proposed categorization of Lesbos ignimbrites by Lamera (2004), it represents the PU unit. The fossil plants of our study come from the layers which are underlying Polichnitos ignimbrite and especially from the upper and lower part of the tephra horizon (ei, eii, b in Fig. 2, left column).

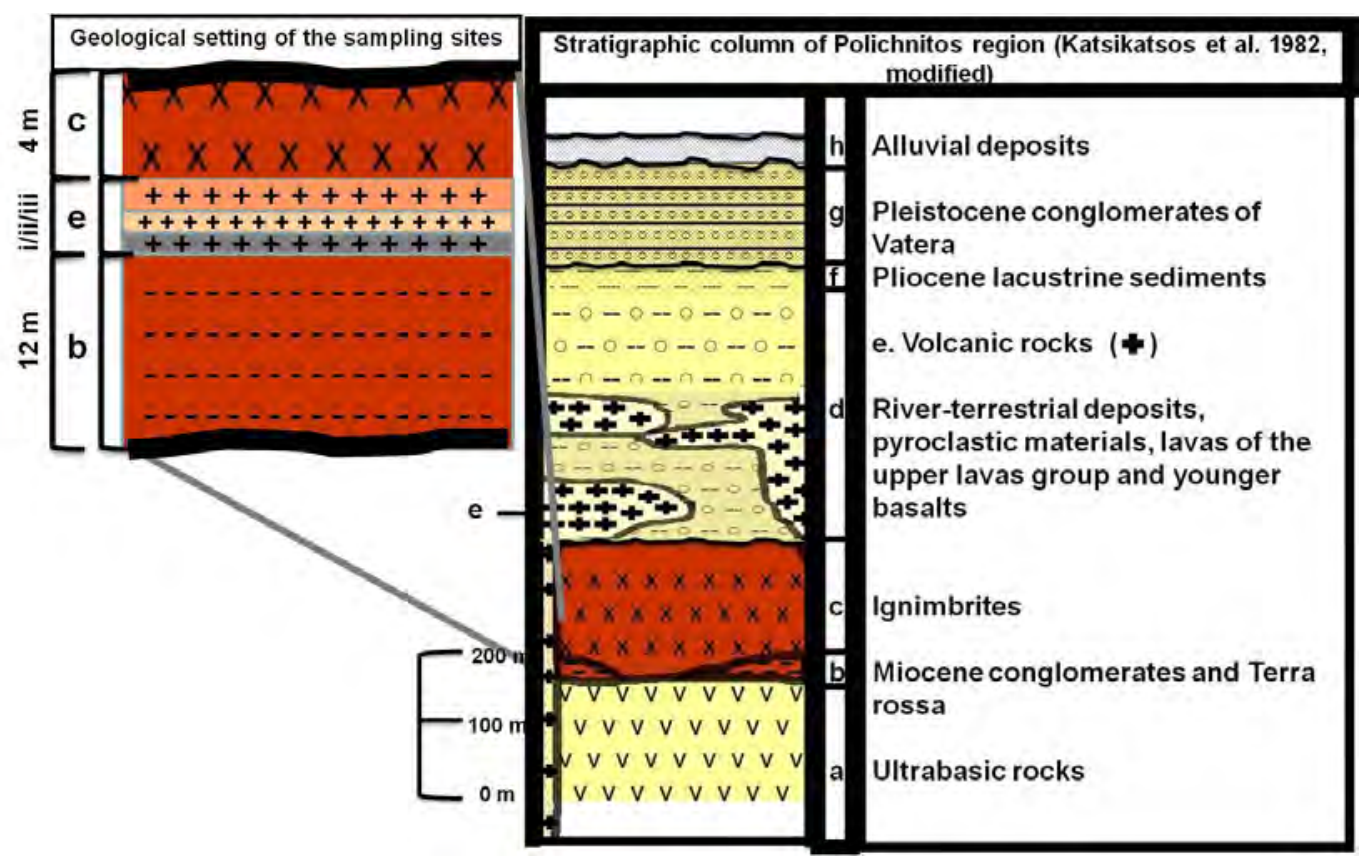

Figure 2 - "Polichnitos - Vatera" area stratigraphic column (from the bottom to the top layer) according to Katsikatsos et al. (1982), modified and the geological setting of the new fossiliferous sites. 


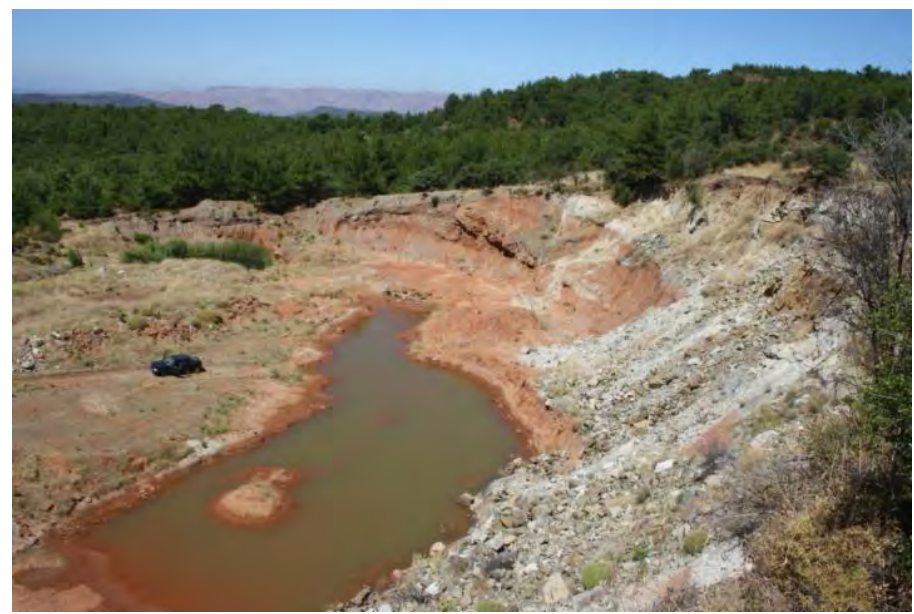

Figure 3 - An example of the outcrops of the localities in Polichnitos region (Locality: DMAL, date: 21/08/11).

\section{Materials and Methods}

During 2011 and 2012 almost 400 specimens were collected by one of us (DM) from six new localities in Polichnitos region. The fossil plants were photographed, their dimensions were measured and they were catalogued. Thin slides for more than 70 samples were prepared (three for each sample: transversal, radial and tangential) in order to study their anatomical features under the microscope.

The thin sections were observed under an Olympus BX51 microscope, in the facilities of Charles University, Prague. Data tables were subsequently created using the Microsoft Office Excel. The anatomical description is in accordance with the IAWA Hardwood List (IAWA Committee 1989) and Wheeler (1986) for angiosperms and the IAWA Softwood List (IAWA Committee 2004) for conifers. In several steps of the study the ArcMap - ArcGIS Program was used, in order to have the already existing knowledge and the new data of the palaeogeographical history of Lesbos Island portrayed.

In Polichnitos region two fossiliferous sites are known (Figure 4):

1. Rougada from which one fossil trunk had been found [Taxaceoxylon biseriatum SÜSS \& VELITZELOS]. The tree trunk is ash-gray color, is $12.5 \mathrm{~m}$ long with a diameter ranging from 80 to $95 \mathrm{~cm}$ and was embedded in an ignimbrite layer (Süss \& Velitzelos, 1994a).

2. Vatera where the Pliocene vertebrate fauna was discovered and studied by the University of Athens (Dermitzakis, 2002).

Among the material that was collected there were also carbonized fossils (Fig. 5a), or permineralised (Fig. 5b) with the great majority of them having the wood, the bark and the extraxylary tissues preserved in a detailed way.

\section{Systematical Part}

\subsection{Historical Research of the Fossil Plants of Lesbos Island}

From 1845 till 2012, 25 species of gymnosperm wood and only 5 species of angiosperm wood have been identified in the Neogene palaeoflora of Lesbos Island, while in some of them there is also information about their preservation. This information is of great value for the taphonomic processes (Appendix). Moreover the references concerning the angiosperm wood species come from the 19th century. The opposite phenomenon - with 5 gymnosperms and 29 angiosperms occurs at leaves' findings. 


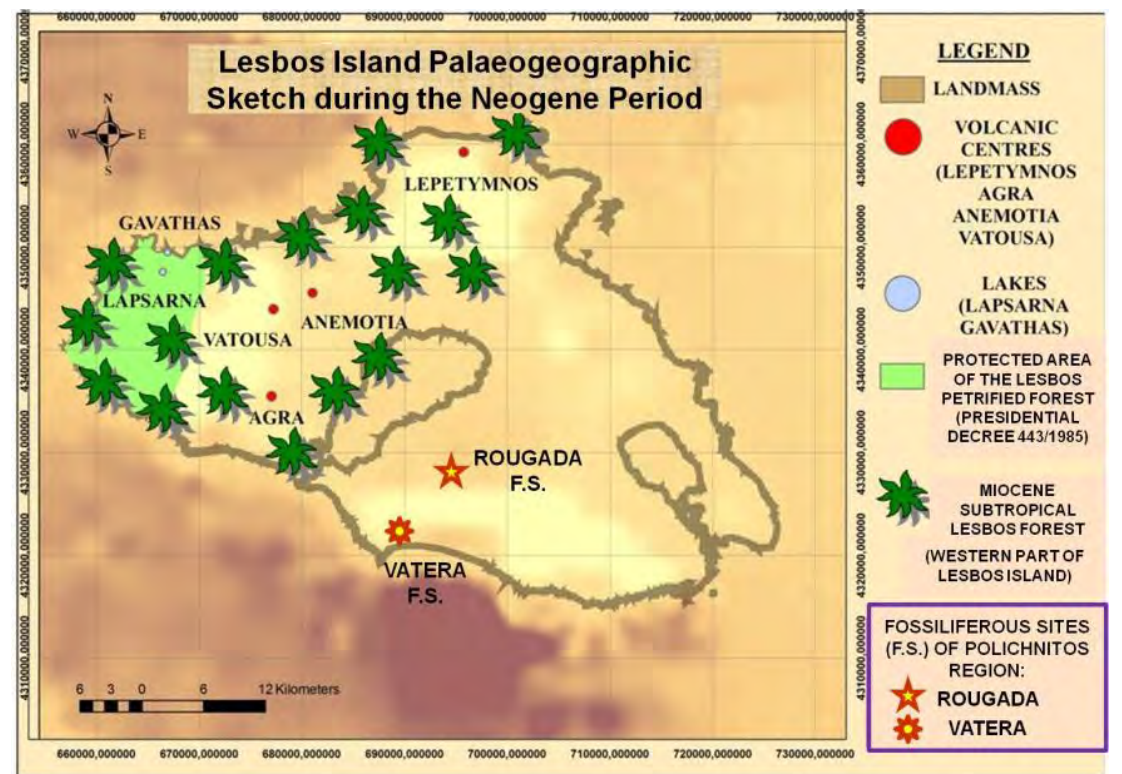

Figure 4 - Palaeogeographic sketch of Lesbos Island during the Neogene Period (Mantzouka 2009a, b, modified).

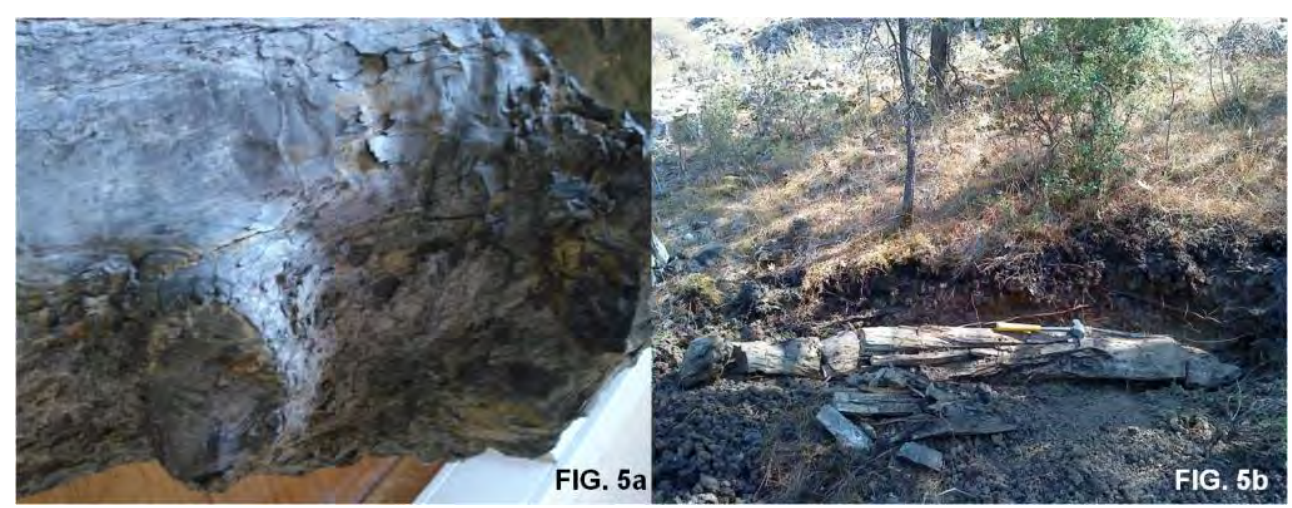

Figure 5 - a. Detail of the external structure of a fossil trunk: the knots and even the bark are preserved (Sample: DMAL 6, date: 21/8/11); b. Among the specimens there is also a lying trunk 2 meters long (Locality: DMRO, date: 17/09/11).

\subsection{Preliminary Results}

Both conifers and angiosperms have been identified in the samples collected from Polichnitos area. Some of the sampling localities contain only one of these two groups; the others have both of them. However, in this paper only the results from the angiosperms are reported.

Among the newly discovered angiosperm woods we were able to identify anatomical characteristics resembling Quercus, Rhamnus and Lauraceae family. So far, we recognize seven wood specimens which are similar to the later family according to their typical features as described by Richter in Metcalfe (1987): wood with frequently diffuse porous, vessel solitary or in radial multiples (never exclusively solitary), alternate intervessel pits and tyloses, paratracheal parenchyma, rays 1-3-(5)-seriate, and heterocellular fibers with pitting on radial walls only. Such a fossil wood can be attributed to the morphogenus Laurinoxylon FELIX.

Concerning lauraceous woods, they were categorized in different groups, based on their oil cells characteristics. According to Richter (1981) the oil and/or mucilage cells can be of potential 
diagnostic value, since the difference in their shape and distribution can lead to different taxonomic groups. There are three different groups of idioblasts connected to: a. the ray parenchyma, and $b$. the vertical strand parenchyma or c. isolated from parenchyma tissues, embedded among the fibers). Three types of lauraceous woods were observed: 1) three samples (Fig. 6b, 7) with oil and/or mucilage cells (idioblasts) connected only to the ray cells, 2) three samples with idioblasts connected to the ray cells and among the fibers and 3) one sample with oil and/or mucilage cells in rays, axial parenchyma and among the fibers. However, a more detailed study is required to obtain solid conclusion.

The samples that have been attributed to the Lauraceae, have some macroscopic characteristics in common: they belong to small stems, which are enclosed to volcanic material (Fig. 6a, b), they are silicified, light, porous, whitish red-brown with distinct growth ring boundaries that can be seen with naked eye, while, most of the times, there is a strange coloration type of circles (possible because of inclusions, of an insect impact or due to mineralization).

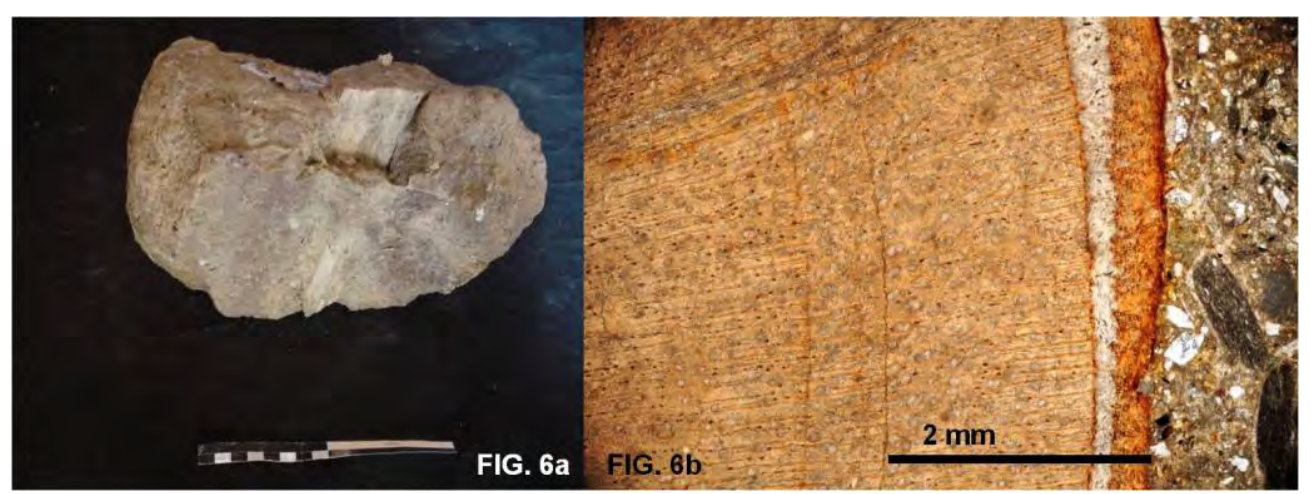

Figure 6 - a. The stem of Laurinoxylon type enclosed in volcanic material (sample DMDA 2, dimensions in cm: 18x9x4); b. A stem/branch of type 1 of Laurinoxylon (sample DM 17) enclosed in volcanic material (transversal section No. DM17a). The occurrence of the growth ring boundaries is also shown.

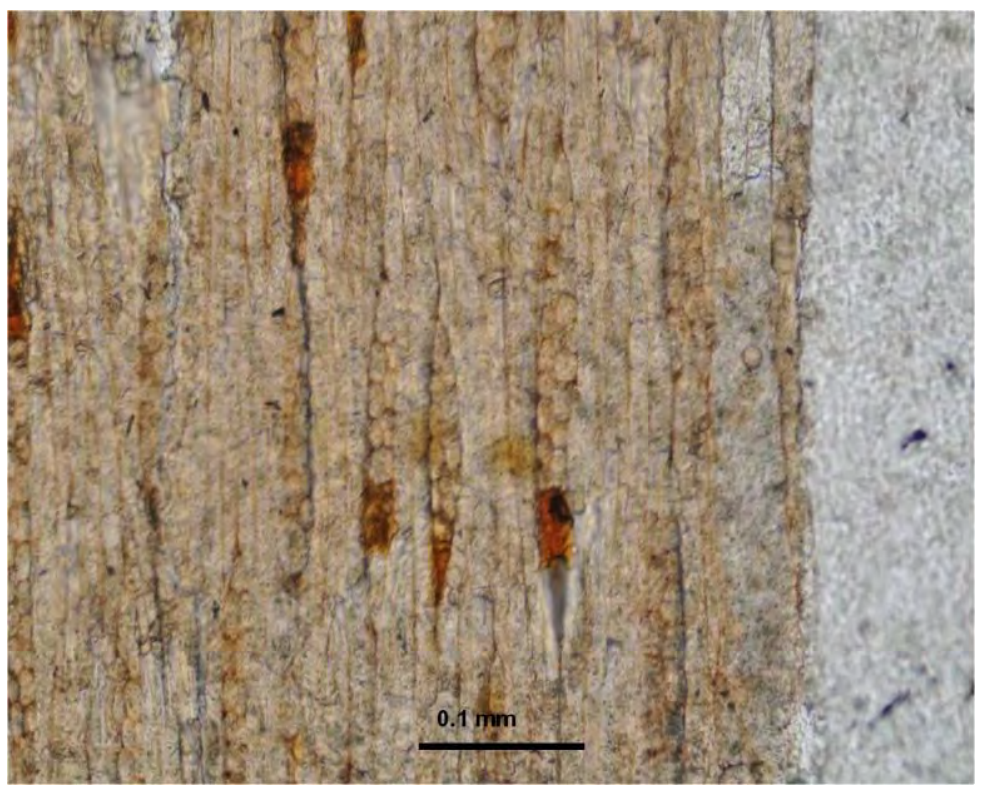

Figure 7 - The oil and/or mucilage cells associated only with the ray parenchyma cells from the same sample DM17 (tangential section No. DM17c). 


\section{Conclusions}

This paper presents preliminary results of a study during which new localities of palaeobotanical interest were discovered in the region of Polichnitos (Vatera) in Lesbos Island; an area that was already well known for its palaeofauna findings. The microscopical study of the collected samples brings new data to the Neogene palaeobotanical record of the Island. Through the study of the new samples there is going to be an effort for collecting as much data as possible in order to follow the 'whole - plant' concept (Sakala 2004) and put together the pieces of the puzzle of reconstructing Lesbos palaeoflora species. Since September of 2012, the whole Island of Lesbos belongs to the Global Geoparks Network of Unesco, which is a recognition of the diversified and many geosites of the Island. By conducting this study we would like to contribute by showing that the occurrences of the petrified trees in other parts of the Island (i.e. apart from the Western peninsula) are not just sporadic but with the right support, protection and scientific study can become geomorphosites/geosites of great importance for the palaeontological heritage of Greece (Zouros \& Valiakos 2007).

As far as the stratigraphy is concerned further studies could be conducted by volcanologists and petrologists, since there are localities among the plant fossiliferous ones where the fossils are enclosed inside the volcanic material and others where it seems that the fossiliferous horizon is hosted within the ignimbrite or within lahar deposits. This kind of differentiation of the lithological setting could have a different reflection to the process of silicification, to the palaeoenvirmonment (e.g. the silicification is faster in volcanic lahars) and also could provide more information about the preservation of fossils (Ballhaus et al. 2012). Furthermore, future radiometric dating of specific volcanic layers in the sampling areas will enable the characterization of a biozone and of an exact age.

\section{Acknowledgments}

Special thanks to Prof. EvangelosVelitzelos, also to the Natural History Museum of the Lesbos Petrified Forest and to the Natural History Collection of Vrisa - part of the Museum of Palaeontology and Geology of University of Athens for providing a part of the needed literature, to Prof. Georgia Pe-Piper for the important advices for the geology of the new fossiliferous localities, to Prof. Nikolaos Christodoulakis, to Prof. George Theodorou for their collaboration and help concerning the new findings and to Dr Elizabeth Stathopoulou and PhD Candidate Mrs Olga Koumoutsakou for their great help for the preparation of the thin slides. Special thanks also to the Institute of Geology and Paleontology, Faculty of Science, Charles University in Prague, to the Department of Historical Geology \& Paleontology, Faculty of Geology \& Geoenvironment, National and Kapodistrian University of Athens and to the Faculty of Botany, Department of Biology, for the permission of using their facilities for the achievement of the scientific anatomic description and consequently taxonomic identification of the new material. This research was partly supported by the grant MSM0021620855 and PRVOUK P44 project, Faculty of Science, Charles University.

\section{References}

Ballhaus C., Gee C.T., Bockrath C., Greef K., Mansfeldt T. and Rhede D. 2012. The silicification of trees in volcanic ash-An experimental study, Geochimica et Cosmochimica Acta 84, p. $62-74$.

Dermitzakis M. (ed) 2002. "On Late Plio/Pleistocene extinction and evolution in the Paleartic. The Vatera site". Annales Géologiques des Pays Helleniques. Vol. 1/39. Athenes, Department de Geologie, Panepistimioupolis. Sponsored: Ministery of Aegean, Prefecture of Lesbos G.S.R.T. \& Municipality of Polichnitos. 
Fliche P. 1898. Note sur les bois fossiles de Metelin, Appendice in De Launay, L. 1898, Etudes geologiques sur la Mer Egee. La geologie des iles de Metelin (Lesbos), Lemnos et Thasos. Paris, p. 141-151.

Fytikas M., Innocenti F., Manetti P., Mazzuoli R., Peccerillo A. and Villari L. 1984. Tertiary to Quaternary evolution of volcanism in the Aegean region, in: The Geological Evolution of the Eastern Mediterranean, eds: Dixon J.E. and Robertson A.H.F., Spec. Publ. Geol. Soc. London, No17, p.687-699.

Gregory M., Poole I. and Wheeler, E.A. 2009. Fossil dicot wood names. An annotated list with full bibliography, IAWA Journal, Supplement 6, 2009.

Hecht J. 1972. Geological map of Greece, 1:50.000, Lesbos Island - Plomari/Mytilene.

Hecht J. 1974. Geological map of Greece, 1:50.000, Lesbos Island - Polichnitos.

IAWA Committee 2004. Richter, H. G.; Grosser, D.; Heinz, I. \& Gasson, P. E. (eds.), IAWA List of microscopic feature for softwood identification, IAWA Journal 25: 1-70.

IAWA Committee. 1989. Wheeler, E. A.; Baas, P. \& Gasson, P.E. (eds.), IAWA list of microscopic features for hardwood identification, IAWA Bulletin n.s. 10 (3): 219-332. Leiden, The Netherlands.

Katsikatsos G., Mataragas D., Migiros G. and Triantaphyllis E. 1982. Geological study of Lesbos Island. I.G.M.E. (Internal report in greek) Athens. p.p.92.

Katsikatsos G., Migiros G., Triantaphyllis M. and Mettos A. 1986. Geological structure of internal Hellenides (E. Thessaly - SW Macedonia - Euboea - Attica - northern Cyclades Islands and Lesbos), Geol. \& Geoph. Res. Sp. Vol. 191-212.

Lamera S. 2004. The Polichnitos Ignimbrite of Lesbos island, PhD Thesis. University of Patras, Department of Geology, p.p. 272

Mantzouka D. 2009a. Palaeogeographical study of Lapsarna area (Lesbos Island) based on the new palaeontological findings of the lower Miocene period, Master thesis, Department of Geography. University of Aegean. p.p. 143 (in greek).

Mantzouka D. 2009b. Palaeogeographical study of Lapsarna area according to palaeontological findings of the lower Miocene period (fish otoliths) "Earth heritage and nature conservation: Geopark's management and action plans on sustainable tourism", Proceedings of the International Conference \& Intensive course on Geoparks, Lesbos, Greece.

Metcalfe C.R. 1987. Anatomy of the dicotyledons: Vol. III Magnoliales, Illiciales and Laurales. 2nd Ed. Clarendon Press, Oxford.

Mountrakis D. 1983. Structural geology of the North Pelagonian zone s.l. and geotectonic evolution of the internal Hellenides. Unpubl. Habilitation, Univ. Thessaloniki, 283.

Mountrakis D. 1986. The Pelagonian zone in Greece: a polyphase deformed fragment of the Cimmerian continent and its role in the geotectonic evolution of East Mediterranean, Journal of Geology 94, p.p. 335 - 347.

Pe-Piper G. 1980. The Cenozoic volcanic sequence of Lesbos, Greece. Z. Dt. Geol. Ges., 131, 889901.

Pe-Piper G. and Piper D.J.W. 1993. Revised stratigraphy of the Miocene volcanic rocks of Lesbos Greece. Neues Jahrbuch für Geologie und Palaontologie, Mh., H.2, 97-110.

Richter H.G. 1981. Anatomie des sekundären Xylems und der Rinde der Lauraceae. Sonderbände des Naturwissenschaftlichen Vereins in Hamburg. p.p 148.

Sakala J. 2004. The 'Whole-Plant' concept in palaeobotany with examples from the Tertiary of northwestern Bohemia, Czech Republic with particular reference to fossil wood, PhD Thesis, Université Pierre-et-Marie, Paris \& Charles University, Prague. p. 1-94.

Selmeier A. and Velitzelos E. 2000. Neue Aufsammlungen von verkieselten Holzresten aus tertiären Schichten Griechenlands (Lesbos, Kastoria, Thrakien), Mitt. Bayer. Staatsslg. Palaeont. Hist. Geol. 40, 213-227.

Süss H. 1997. Tetraclinoxylon velitzelosi sp. nova. ein neues fossiles Holz aus tertiären Schichten des Versteinerten Waldes von Lesbos, Feddes Repertorium, 108, 289-298. 
Süss H. 2003. Zwei neue fossile Hölzer der Morphogattung Ginkgoxylon SAPORTA emend. SÜSS aus tertiären Schichten der Insel Lesbos, Griechenland, mit einer Übersicht über Fossilien mit ginkgoaler Holzstruktur, Feddes Repertorium, 114, 5-6, 301-319.

Süss H. and Velitzelos E. 1994a. Ein neues fossiles Koniferenholz, Taxaceoxylon biseriatum sp. nova, aus tertiären Schichten der Insel Lesbos, Griechenland, Feddes Repertorium,105, 257-269.

Süss H. and Velitzelos E. 1994b. Zwei neue tertiäre Hölzer der Gattung Pinoxylon KNOWLTON emend, READ aus dem Versteinerten Wald von Lesbos, Griechenland, Feddes Repertorium, 105, 403-423.

Süss H. and Velitzelos E. 1997. Fossile Hölzer der Familie Taxodiaceae aus tertiären Schichten des Versteinerten Waldes von Lesbos, Griechenland, Feddes Repertorium, 108, 1-30, 5 Abb., 7 Taf.

Süss H. and Velitzelos E. 1998. Thujoxylon antissurn sp. nov.. ein fossiles Wurzelholz aus tertiären Schichten des Versteinerten Waldes von Lesbos, Griechenland, Feddes Repertorium, 109, 341-350.

Süss H. and Velitzelos E. 1999. Chimairoidoxylon gen. nov. sp. nova, ein endemisches Holzfossil aus dem Tertiar von Lesbos, Griechenland, Feddes Repertorium, 110, 329-339.

Süss H. and Velitzelos E. 2000. Zwei neue fossile Hölzer der Formgattung Podocarpoxylon GOTHAN aus tertiären Schichten der Insel Lesbos, Griechenland, Feddes Repertorium, $111,135-149$.

Süss H. and Velitzelos E. 2001. Chimairoidoxylon conspicuum sp. nova, ein neues fossiles Holz der Formgattung Chimairoidoxylon SÜSS \& VELITZELOS emend. SÜSS, mit einer Übersicht über das Vorkommen fossiler Hölzer auf der Insel Lesbos, Griechenland, Feddes Repertortium, 112, 149-157.

Süss H. and Velitzelos E. 2009. Zwei neue fossile Hölzer der Morphogattung Pinoxylon KNOWLTON emend. READ aus dem Tertiär der Insel Lesbos, Griechenland, Feddes Repertorium, 120, 3-14.

Süss H. and Velitzelos E. 2010. Lesboxylon gen. nov., eine neue Morphogattung mit dem Typus Lesbosoxylon ventricosuradiatum sp.nova aus dem Tertiar der Insel Lesbos, Griechenland, Feddes Repertorium, 121, 1-2, 18-26.

Theophrastus. Complete Works: On Plants History, On Stones (Athens: Kaktos Editions, 1998)

Thomaidou, E., 2009. The geological structure of Lesbos Island PhD thesis, AUTH, p. 39.

Unger F. 1845. Synopsis plantarum fossilium. Lipsiae apud Leopoldum Voss, Bibliopolam.

Unger F. 1847. Chloris protogaea. Beitrage zur Flora der Vorwelt. Leipzig.

Unger F. 1850. Genera et species plantarum fossilium, Wien.

Velitzelos, E., Petrescu, I. and Symeonidis N. 1981a. Tertiary Plant Reminants from Aegiis.

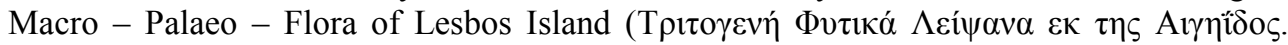

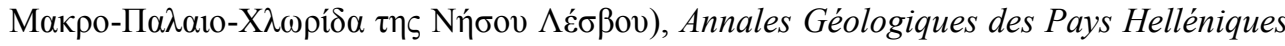
XXX/ 2-1981, 500-514, Athens.

Velitzelos E., Petrescu I. and Symeonidis N. 1981b. Tertiäre Pflanzenreste von der Ägäischen Insel Lesbos (Griechenland) [Tertiary Plant Fossils from Lesbos Island (Aegean, Greece)], Cour. Forsch. Inst. Senckenberg, 50, 49-50, Frankfurt.

Velitzelos E. and Zouros N. 2008. The Petrified Forest of Lesbos, Natural History Museum of the Lesbos Petrified Forest, Topio Publications, Athens, p.p. 155.

Velitzelos E., Zouros N. and Velitzelos D. 1999. Contribution to the study of the palaeoflora of the Lesbos Petrified Forest. Proceedings of the International Symposium 'Protected natural areas and environmental education'. Sigri, Lesbos Island.

Wheeler E.A. 1986. Vessels per square millimetre or vessel groups per square millimetre? IAWA Bull. n.s. 7, 73-74.

Zouros N. and Valiakos H. 2007. Geosite assessment and management, Proceedings of 8th PanHellenic Geographical Conference of the Hellenic Geographic Society, Athens, Vol. 1, 612-620. 


\section{APPENDIX:}

\section{GYMNOSPERM WOOD}

Thujoxylum peucinum UNGER emend. SÜSS \& VELITZELOS [Lesbos unknown locality: ?Sigri described by Unger $(1847$, p.31, 32). The genus has been emended by Süss \& Velitzelos (1998)].

Taxoxylum priscum UNGER [Lesbos unknown locality: ?Sigri described by Unger (1847, p.33, 34). Revised as Taxoxylon priseum by Unger $(1850$, p.390, 391)].

Peuce lesbia UNGER (= Cedroxylon lesbium KRAUS) [Lesbos unknown locality: ?Sigri described by Unger (1844, p. 34, 37, Tab. X)].

Cedroxylon sp. [Lesbos - western part: Ordymnos seashore and NE part of Ordymnos described by Fliche (1898, p. 143, 148) (lignitic and permineralized samples)].

Pityoxylon sp. [Lesbos - western part: NE part of Ordymnos described by Fliche (1898, p. 149) (permineralized sample)].

Taxaceoxylon biseriatum SÜSS \& VELITZELOS [Lesbos: Rougada - Polichnitos region, described by Süss \& Velitzelos (1994, p. 259, Taf. I, II)].

Pinoxylon paradoxum (SÜSS \& VELITZELOS) SÜSS \& VELITZELOS [Lesbos - western part: Bali Alonia, described by Süss \& Velitzelos (1994, p. 407, Taf. I, II, III, IV). In 2010 it was revised as Lesbosoxylon paradoxum by SÜSS \& VELITZELOS].

Pinoxylon pseudoparadoxum (SÜSS \& VELITZELOS) SÜSS \& VELITZELOS [Lesbos - western part: Bali Alonia, described by Süss \& Velitzelos (1994, p. 409, Taf. V). In 2010 it was revised as Lesbosoxylon pseudoparadoxum by SÜSS \& VELITZELOS].

Taxodioxylon gypsaceum (GOEPPERT) KRÄUSEL [Lesbos - western part: Sarakina, Molyvos, Bali Alonia and Lapsarna-Gavathas (Antissa) described by Süss \& Velitzelos (1997, p. 5, Taf. I)].

Taxodioxylon albertense (PENHALLOW) SHIMAKURA [Lesbos - western part: Bali Alonia and Sarakina, described by Süss \& Velitzelos (1997, p. 7, Taf. II, III)].

Taxodioxylon pseudoalbertense M. NISHIDA \& H. NISHIDA [Lesbos - western part: Sarakina, described by Süss \& Velitzelos (1997, p. 11, Taf. IV)].

Taxodioxylon megalonissum SÜSS \& VELITZELOS [Lesbos - western part: Nisiopi (Megalonissi) described by Süss \& Velitzelos (1997, p. 12, Taf. V)].

Taxodioxylon sp. [Lesbos - western part described by Süss \& Velitzelos (1997, p. 14)].

Glyptostroboxylon microtracheidae SÜSS \& VELITZELOS [Lesbos - western part described by Süss \& Velitzelos (1997, p. 16, 18, 19, Taf. VI, VII)].

Tetraclinoxylon velitzelosi SÜSS [Lesbos - western part: Bali Alonia, Sarakina, Sigri, Gavathas described by SÜSS (1997, p. 290, 294, 295, Taf. I, II)].

Thujoxylon antissum SÜSS \& VELITZELOS [Lesbos - western part: Lapsarna (Antissa) described by Süss \& Velitzelos (1998)].

Chimairoidoxylon lesboense SÜSS \& VELITZELOS [Lesbos - western part: Nissiopi (Megalonissi) and Gavathas described by Süss \& Velitzelos (1999, p. 330-334, Taf. I, II, III)].

Podocarpoxylon articulatum SÜSS \& VELITZELOS [Lesbos - western part: Bali Alonia (main Petrified Forest Park) described by Süss \& Velitzelos (2000, p. 138, Taf. I, II)].

Podocarpoxylon graciliradiatum SÜSS \& VELITZELOS [Lesbos - western part: Bali Alonia (main Petrified Forest Park), found lying next to Taxodioxylon sp. SÜSS \& VELITZELOS (1994) described by Süss \& Velitzelos (2000, p. 140, Taf. III, IV)].

Chimairoidoxylon conspicum SÜSS \& VELITZELOS [Lesbos - western part: Gavathas, Bali Alonia and Eressos described by Süss \& Velitzelos (2001, p. 151, Taf. I, II)].

Ginkgoxylon lesboense SÜSS [Lesbos - western part described by Süss (2003, p. 304-307, Taf. I, II)].

Ginkgoxylon diversicellulatum SÜSS [Lesbos - western part described by Süss (2003, p. 307-310, Taf. III, IV)].

Pinoxylon diversiradiatum SÜSS \& VELITZELOS [Lesbos - western part: Eressos, described by Süss \& Velitzelos (2009, p. 4, Taf. I, II). In 2010 it was revised as Lesbosoxylon diversiradiatum by SÜSS \& VELITZELOS]

Pinoxylon graciliradiatum SÜSS \& VELITZELOS [Lesbos - western part: Eressos, described by Süss \& Velitzelos (2009, p. 6, Taf. III, IV). In 2010 it was revised as Lesbosoxylon graciliradiatum by SÜSS \& VELITZELOS].

Lesbosoxylon diversiradiatum (SÜSS \& VELITZELOS) SÜSS \& VELITZELOS [Lesbos - western part: Eressos. Revision of the originally described Pinoxylon diversiradiatum by Süss \& Velitzelos $(2009,2010, p$. 22)]. 
Lesbosoxylon graciliradiatum (SÜSS \& VELITZELOS) SÜSS \& VELITZELOS [Lesbos - western part: Eressos Revision of the originally described Pinoxylon graciliradiatum by Süss \& Velitzelos (2009, 2010, p. 22)].

Lesbosoxylon ventricosuradiatum SÜSS \& VELITZELOS [Lesbos - western part: Eressos, described by Süss \& Velitzelos (2010, p. 19, Taf I, II)].

Lesbosoxylon paradoxum (SÜSS \& VELITZELOS) SÜSS \& VELITZELOS [Lesbos - western part: Bali Alonia main Petrified Forest Park. Revision of the originally described Pinoxylon paradoxum by Süss \& Velitzelos (1994, 2010 p. 22)].

Lesbosoxylon pseudoparadoxum (SÜSS \& VELITZELOS) SÜSS \& VELITZELOS [Lesbos - western part: Chamandroula. Revision of the originally described Pinoxylon pseudoparadoxum by Süss \& Velitzelos (1994, 2010, p. 22)].

ANGIOSPERM WOOD

Juglandinium mediterraneum (UNGER) [Lesbos unknown locality: ?Sigri described by Unger (1845, p. 241). Syn: Juglandoxylon mediterraneum (UNGER) (KRAUS $1882 \mathrm{a}, \mathrm{b}$ )].

Mirbellites lesbius (UNGER) [Lesbos unknown locality: ?Sigri described by Unger $(1845$, p.. 241, 242). Syn: Juglandinium mediterraneum (Unger 1850; Fliche 1898; Duperon 1988) Syn: Juglandoxylon mediterraneum (UNGER) (KRAUS $1882 \mathrm{a}, \mathrm{b})]$.

Brongniartites graecus UNGER [Lesbos unknown locality: ?Sigri described by Unger (1845, p. 264)].

Palmoxylon sp. [Lesbos - western part: Ordymnos seashore described by Fliche (1898, p. 144) (lignitic sample, it looked also like Sabal or Chamaerops)].

Ebenoxylon sp. [Lesbos - western part: Ordymnos seashore described by Fliche (1898, p. 146) and related to modern Diospyros (lignitic sample). Note: Süss 1987 said ?Eben.].

Betulaceae (? Alnus), Euphorbiaceae (?), Fagaceae (? Fagus, ? Quercus), Lauraceae (? Laurus, ? Cinnamomum, ?), Leguminosae (? Robinia), Monimiaceae (?), Myrtaceae (?), Platanaceae (? Platanus) [Lesbos - western part: Eressos, Mesotopos. Tab. 1, p. 218 in Selmeier \& Velitzelos 2000]

\section{LEAVES}

PTERYDOPHYTES

Pronefrium stiriacum (UNGER) KNOBLOCH \& KVACEK [Lesbos - western part: Eressos described by Velitzelos (1993)]

GYMNOSPERMS

Tetraclinis sp. [Lesbos - western part described by Velitzelos (1993)]

Pinus sp. [Lesbos - western part. Referred by Velitzelos \& Zouros (2008)]

Cunninghamia miocenica ETTINGS HAUSEN [Lesbos - western part. Referred by Velitzelos \& Zouros (2008)]

Sequoia abietina (BRONG.) KNOBLOCH [Lesbos - western part. Referred by Velitzelos \& Zouros (2008)]

Tetraclinis salicornoides (UNGER) KVAČEK [Lesbos - western part. Referred by Velitzelos \& Zouros (2008)]

\section{ANGIOSPERMS}

Cinnamomum polymorphum HEER sensu GRANGEON [Lesbos - western part: at the outcrop of the road Antissa-Sigri described by Velitzelos et al. (1981)]

Laurus sp. [Lesbos - western part: at the outcrop of the road Antissa-Sigri described by Velitzelos et al. (1981)]

Laurus primigenia UNGER [Lesbos - western part. Referred by Velitzelos et al. (1999)]

Litsea primigenia (UNGER) TAKHT. [Lesbos - western part: at the outcrop of the road Antissa-Sigri described by Velitzelos et al. (1981)]

Lindera ovata KOLAK. [Lesbos - western part: at the outcrop of the road Antissa-Sigri described by Velitzelos et al. (1981)]

Oreodaphne heeri GAUDIN [Lesbos - western part: at the outcrop of the road Antissa-Sigri described by Velitzelos et al. (1981)]

Lauraceae [Lesbos - western part: at the outcrop of the road Antissa-Sigri described by Velitzelos et al. (1981)]

Daphnogene polymorpha AL.BRAUN ETT. [Lesbos - western part. Referred by Velitzelos et al. (1999)]

Quercus sp. [Lesbos - western part. Referred by Velitzelos et al. (1999)]

Quercus apocynophyllum ETT. [Lesbos - western part: at the outcrop of the road Antissa-Sigri described by Velitzelos et al. (1981)] 
Pungiphyllum crutiatum (AL. BRAUN) FRANKENHÄUSER et WILDE (= Quercus cruciata AL. BRAUN) [Lesbos - western part described by Velitzelos (1993) as Quercus cruciata]

Pungiphyllum crutiatum (AL. BR.) FRANKENHÄUSER et WILDE [Lesbos - western part. Referred by Velitzelos et al. (1999)]

Carpinus pliofaurei RATIANI forma helladae VELITZELOS et al.n. f. [Lesbos - western part: at the outcrop of the road Antissa-Sigri described by Velitzelos et al. (1981)]

Carpinus uniserrata (KOLAKOVSKI) RATIANI (?) [Lesbos - western part: at the outcrop of the road Antissa-Sigri described by Velitzelos et al. (1981)]

Alnus cycladum UNGER forma parvifolia VELITZELOS et al. n. f. [Lesbos - western part: at the outcrop of the road Antissa-Sigri described by Velitzelos et al. (1981)]

Alnus cycladum UNGER [Lesbos - western part. Referred by Velitzelos et al. (1999)]

Populus balsamoides GOEPP. [Lesbos - western part: at the outcrop of the road Antissa-Sigri described by Velitzelos et al. (1981)]

Populus sp. [Lesbos - western part: at the outcrop of the road Antissa-Sigri described by Velitzelos et al. (1981)]

Tilia sp. [Lesbos - western part: at the outcrop of the road Antissa-Sigri described by Velitzelos et al. (1981)] Diospyros brachysepala AL. BRAUN. [Lesbos - western part: at the outcrop of the road Antissa-Sigri described by Velitzelos et al. (1981)]

Myrsinites sp. [Lesbos - western part: at the outcrop of the road Antissa-Sigri described by Velitzelos et al. (1981)]

Rhus sp. [Lesbos - western part: at the outcrop of the road Antissa-Sigri described by Velitzelos et al. (1981)]

Sapotaceae (?) [Lesbos - western part: at the outcrop of the road Antissa-Sigri described by Velitzelos et al. (1981)]

Rubus sp. [Lesbos - western part. Referred by Velitzelos \& Zouros (2008)]

Engelhardia sp. [Lesbos - western part. Referred by Velitzelos et al. (1999)]

Engelhardia orsbergensis (WESSEL et WEBER) JÄHNICHEN et al. [Lesbos - western part. Referred by Velitzelos \& Zouros (2008)]

Phoenix sp. [Lesbos - western part described by Velitzelos (1993)]

Platanus sp. [Lesbos - western part described by Velitzelos (1993)]

Acer sp. [Lesbos - western part described by Velitzelos (1993)] 